\title{
SKALA KARAKTER TOLERANSI: KONSEP DAN OPERASIONAL ASPEK KEDAMAIAN, MENGHARGAI PERBEDAAN DAN KESADARAN INDIVIDU
}

\author{
Agus Supriyanto $^{1)}$, Amien Wahyudi ${ }^{2)}$ \\ ${ }^{1}$ Fakultas Keguruan dan Ilmu Pendidikan, Universitas Ahmad Dahlan Yogyakarta \\ agus.supriyanto@bk.uad.ac.id \\ ${ }^{2}$ Fakultas Keguruan dan Ilmu Pendidikan, Universitas Ahmad Dahlan Yogyakarta \\ amien.wahyudi@bk.uad.ac.id
}

\begin{abstract}
Abstrak
Pendidikan karakter di sekolah bagian integral dari program penguatan karakter. Karakter toleransi berfungsi untuk menumbuhkan kompetensi multikultural siswa. Fenomena kasus intoleransi perlu dicegah melalui pengembangan pendidikan karakter di sekolah. Tujuan penelitian untuk menemukan butir-butir pernyataan yang valid dan reliabel pada instrumen skala karakter toleransi. Penelitian ini menggunakan pendekatan mixed methods. Rancangan penelitian menggunakan rancangan transformatif sekuensial. Intrument penelitian ini melalui studi dokumentasi beruapa analisis teks, wawancara, dan survei. Analisis penelitian menggunakan analisis deskriptif kualitatif tentang kajian jurnal dan buku sebagai studi dokumentasi, forum group dicussion penentuan butir-butir pernyataan dan analisis deskriptif kuantitatif dari hasil uji beda untuk mengetahui validitas dan reliabilitas instrumen karakter toleransi. Temuan mengungkap konsep dan operasionalisasi skala karakter toleransi melalui tiga aspek, yaitu (1) aspek kedamaian meliputi indikator peduli, ketidaktakutan, dan cinta, (2) aspek menghargai perbedaan dan individu meliputi indikator saling menghargai satu sama lain, menghargai perbedaan orang lain, dan menghargai diri sendiri, serta (3) aspek kesadaran meliputi indikator menghargai kebaikan orang lain, terbuka, reseptif, kenyamanan dalam kehidupan, dan kenyamanan dengan orang lain. Skala karakter toleransi memiliki 39 butir pernyataan yang valid. Koefisien reliabilitas skala karakter toleransi adalah 0,777 yang termasuk dalam kategori reliabilitas tinggi. Skala karakter toleransi dapat digunakan untuk mengidentifikasi tingkat karakter toleransi.
\end{abstract}

\section{Kata Kunci: Karakter Toleransi}

\begin{abstract}
Character education in schools an integral part of the character strengthening programs. Tolerance character serves to foster multicultural competence in students. The phenomenon of intolerance cases should be prevented through the development of character education in schools. The goal of research to find a grain of valid and reliable statements on the instrument scale tolerance character. This research uses mixed methods approach. Design research uses sequential transformative design. Instrument this research through documentation study in form of text analysis, interview, and survey. Research analysis used qualitative descriptive analysis about study of journals and books as documentation studies, and forum group discussion for the determination of statement items and quantitative descriptive analysis from different test results to know validity and reliability of instrument tolerance character. The findings reveal the concept and operationalization of tolerant character scale through three aspects: (1) peace aspects include indicators care, fear, and love, (2) value diversity and individual aspects include indicators respect each other, respect differences of others, and respect ourselves, and (3) awareness aspects include indicators of appreciating the goodness of others, open,
\end{abstract}


receptive, comfort in life, and comfort with others. Tolerance character scale has 39 valid statement items. Tolerance character scale reliability coefficient is 0.777 which was included in category of high reliability. Scale tolerance character can be used to identify the level of tolerance character.

Keywords: Character Tolerance

\section{PENDAHULUAN}

Setiap negara memiliki ragam budaya dan karakter yang khas yang membedakannya dengan negara lain. Keragaman budaya ini dapat menimbulkan kekhasan yang unik pada setiap masyarakat dari bahasa, agama, suku, ras, warna kulit, dan adat istiadat. Padangan positif tentang keragaman menimbulkan persatuan bangsa dengan berbagai tantangan di era globalisasi. Selain pandangan positif keragaman budaya dapat dipandang juga secara negatif salah satu nya yaitu jika masyarakat Indonesia tidak bisa menghargai segala perbedaan dari keragaman manusianya. Penguatan karakter kebangsaan dapat dimulai dari optimalisasi pendidikan karakter berbasis kearifan lokal (Sultoni \& Hilmi, 2015). Pendidikan berbasis nilai menekankan pada realisasi warga negara yang baik, yang memiliki kompetensi holistik dalam pengetahuan, keterampilan, dan sifat berdasarkan nilai-nilai Pancasila atau Lima Prinsip Indonesia atau karakter nasional (Nurdin, 2015).

Kondisi yang diharapkan sesuai dengan uraian di atas belum semuanya berjalan dengan maksimal. Fenomena perilaku yang tidak menghargai perbedaan antar individu dapat menimbulkan perilaku anarkis. Hasil penelitian mengungkap bahwa toleransi cenderung menurun karena ketimpangan pendapatan nasional meningkat (Andersen\& Fetner, 2008). Sikap anti-Eropa sebagai dampak negatif globalisasi terhadap orang-orang yang bekerja dalam profesi mengancam globalisasi dan Eropaisasi cenderung menjadi lebih tidak toleran terhadap imigran dan pekerja asing (Giugni\& Morariu, 2010). Laporan The Wahid Institute tentang kasus pelanggaran kebebasan beragama dan berkeyakinan serta intoleransi di Indonesia pada tahun 2013 yang mencapai 245 peristiwa dan pada tahun 2014 mencapai 154 peristiwa atau turun 40 persen dengan kasus yang terjadi 55 peristiwa yaitu Daerah Istimewa Yogyakarta dengan 21 peristiwa, Sumatera Utara dengan 18 peristiwa, DKI Jakarta dengan 14 peristiwa, Jawa Tengah dengan 10 peristiwa, dan Sulawesi Selatan dengan 10 peristiwa (Setiawan, 2015). Hasil penelitian mengungkap bahwa Sunni dan Syiah menilai dampak kurikulum sekolah sebagai alasan paling penting di balik intoleransi agama, sementara kaum Ahmadiyah dan Kristen menilai literatur yang membenci sebagai alasan dari kasus intoleransi (Khan, Österman, \& Björkqvist, 2017).

Fakta dari kasus intoleransi akibat dari nilai-nilai karakter yang belum terinternalisasi dalam karakter manusia. Pendidikan memiliki peran dalam pengembangan karakter melalui pendidikan karakter. Hasil penelitian menunjukkan keyakinan 
pada siswa dapat mengembangkan keterampilan dan kemampuan berinteraksi secara positif dengan lingkungan dan teman sebayanya (Elias, et.al., 2008; Richardson, Tolson, Huang, \& Lee, 2009). Hasil penelitian menunjukkan bahwa guru sebagai model memberi kontribusi pada pendidikan moral anak-anak, sehingga pembentukan komunitas yang lebih peduli dapat terjadi, dan komunitas tersebut berdampak pada turunnya secara signifikan, perilaku intimidasi, dan nilai tes di sekolah juga mengalami peningkatan hampir 50\%. (Marshall, Caldwell, \& Foster, 2011; Sanderse, 2013). Sekolah memiliki peran bersama untuk mengembangkan karater siswa. Hasil penelitian menunjukkan bahwa orang tua, guru, dan administrator sebagai pemangku kepentingan secara bersama-sama bergabung untuk mendorong siswa mewujudkan nilainilai baik dalam kehidupan yang berkaitan dengan identitas individu yang beragam baik dari segi format maupun substansi kerjasama dalam proses pembentukan identitas nasional yang menghasilkan penguatan secara afektif dan sikap intelektual yang mempengaruhi pengembangan sikap sosial, keterampilan sosial dan sikap spiritual (Parker, Nelson, \& Burns, 2010; Trisiana, 2015; Wang, 2017).

Permasalahan di atas mendorong untuk dikembangkannya sebuah instrumen yang dapat berguna mengetahui tingkat karakter toleransi pada siswa Sekolah Menengah Pertama (SMP). Instrumen yang dikembangkan dapat berupa skala karakter toleransi. Skala karakter toleransi yang dikembangkan ini berdasarkan pada teori yang dikembangkan Tillman (2004) tentang butir-butir refleksi dari karakter toleransi tersebut adalah (a) kedamaian adalah tujuan; (b) toleransi adalah terbuka dan reseptif pada indahnya perbedaan; (c) toleransi menghargai individu dan perbedaan; (d) toleransi adalah saling menghargai satu sama lain; (e) benih dari intoleransi adalah ketakutan dan ketidakpedulian; (f) benih dari toleransi adalah cinta; (g) jika tidak cinta tidak ada toleransi; (h) yang tahu menghargai kebaikan dalam diri orang lain dan situasi memiliki toleransi; (i) toleransi berarti menghadapi situasi sulit; dan (j) toleransi terhadap ketidaknyamanan hidup dengan membiarkan berlalu, ringan, dan membiarkan orang lain. Butir-butir refleksi karakter toleransi tersebut akan mengantarkan kedamaian antar individu di masyrakat.

Instrumen yang dikembangkan akan berguna untuk mengetahui tingkat karakter toleransi siswa SMP. Hasil pengukuran akan menjadi acuan atau dasar pihak-pihak yang bertanggung jawab seperti guru, konselor, atau orang tua siswa untuk meminimalisir permasalahan kasus intoleransi. Masalah intolerasi dapat menjadi masalah serius sekaligus tantangan bagi pihak-pihak yang bertanggung jawab untuk mencegah siswa berperilaku intoleransi.

Kasus intoleransi menjadi masalah serius dan dapat berdampak negatif bagi berbagai kalangan jika tidak segera disadari dan dicari jalan keluarnya. Tillman (2004) menyatakan karakter toleransi sebagai sikap saling menghargai melalui pengertian dengan tujuan 
kedamaian. Toleransi adalah menuju kedamaian. Toleransi disebut sebagai faktor esensi untuk perdamaian. Galtung (1967) mengkonsep makna damai itu sendiri sebagai suatu kondisi internal manusia yang memiliki pikiran damai terhadap dirinya sendiri ketika dihadapkan pada situasi tertentu.

Dampak negatif yang dijelaskan menunjukkan bahwa tingkat karakter toleransi perlu diukur dan segera disadari oleh pihak-pihak yang bertanggung jawab. Hal ini dimaksudkan agar perilaku maladaptif tersebut segera mendapat penanganan jika memang terjadi di kalangan pelajar. Instrumen yang dapat dikembangkan satunya skala karakter toleransi. Sebuah skala sebelum diimplementasikan sebagai alat ukur perlu diuji coba terlebih dahulu sehingga akan diketahui kelayakan instrumen tersebut berdasarkan hasil uji validitas dan reliabilitas. Artikel ini memaparkan tentang proses penyusunan instrumen skala karakter toleransi yang valid dan reliabel, sehingga skala tersebut menjadi skala yang layak untuk mengetahau tingkat karakter toleransi dikalangan siswa.

\section{METODE PENELITIAN}

Penelitian ini menggunakan pendekatan mixed methods. Rancangan penelitian menggunakan rancangan transformatif sekuensial. Hasil penelitian memiliki tujuan untuk menemukan butir-butir pernyataan yang valid dan reliabel pada instrumen skala karakter toleransi.
Intrument penelitian ini melalui studi dokumentasi beruapa analisis teks, wawancara, dan survei. Rancangan penelitian dalam pendekatan mixed methods melalui empat tahap. Pertama, tahap studi literatur di jurnal dan buku ilmiah. Kedua, wawancara penyusunan butir-butir pernyataan melalui forum group discussion (FGD). Ketiga, wawancara mengenai butir-butir pernyataan terhadap ahli dan subyek penelitian. Keempat, pengembangan item pernyataan sesuai aspek. Kelima, survei hasil pengembangan item pernyataan sesuai aspek. Terakhir, menguji validitas dan reliabilitas.

Tahap pertama, menemukan variabel karakter toleransi melalui studi literatur melalui analisis jurnal dan buku ilmiah yang memuat indikator-indikator karakter toleransi. Tahap kedua, forum group discussion (FGD) dengan pakar/ ahli dari hasil temuan indikator toleransi untuk disusun butir-butir pernyataan. Tahap ketiga, butir-butir pernyataan divalidasi oleh empat ahli untuk mengetahui validitas isi dari butirbutir pernyataan pada aspek karakter toleransi. Tahap keempat, pengembangan 60 butir-butir karakter toleransi. Tahap kelima, survei untuk uji coba butir-butir karakter toleransi pada 100 siswa SMP yang tersebar di SMP Se- DIY. Tahap keenam, survei dianalisis untuk mengetahui valid dan reliabel instrument melalui korelasi product moment untuk menentukan tingkat validitasnya dan menggunakan rumus alpha cronbach untuk menentukan tingkat reliabilitasnya. Hasil temuan akan menunjukkan data tentang aspek karakter toleransi dan 
item-item yang valid dan reliabel untuk dapat mengukur karakter toleransi.

Analisis

penelitian menggunakan analisis deskriptif kualitatif tentang kajian jurnal dan buku sebagai studi dokumentasi, forum group dicussion penentuan butir-butir pernyataan, dan hasil validasi ahli tentang isi dari butirbutir pernyataan. Selain analisis deskriptif kualitatif, analisis juga menggunakan analisis deskriptif kuantitatif dari hasil uji beda untuk mengetahui validitas dan reliabilitas instrumen karakter toleransi. Hasil analisis akan menemukan fakta tentang aspek, indikator, dan butirbutir pernyataan dari karakter toleransi siswa SMP.

\section{HASIL DAN PEMBAHASAN}

Hasil temuan dari studi literatur melalui analisis jurnal dan buku ilmiah menjadi rujukan utama untuk mengetahui karakter toleransi. Hasil penelitian Galtung \& Fischer (2013) tentang konsep perdamaian yaitu tidak adanya kekerasan budaya yang melegitimasi kekerasan langsung dan atau struktural. teori yang dikembangkan Tillman (2004) tentang butir-butir refleksi dari karakter toleransi tersebut adalah (a) kedamaian adalah tujuan; (b) toleransi adalah terbuka dan reseptif pada indahnya perbedaan; (c) toleransi menghargai individu dan perbedaan; (d) toleransi adalah saling menghargai satu sama lain; (e) benih dari intoleransi adalah ketakutan dan ketidakpedulian; (f) benih dari toleransi adalah cinta; (g) jika tidak cinta tidak ada toleransi; (h) yang tahu menghargai kebaikan dalam diri orang lain dan situasi memiliki toleransi; (i) toleransi berarti menghadapi situasi sulit; dan (j) toleransi terhadap ketidaknyamanan hidup dengan membiarkan berlalu, ringan, dan membiarkan orang lain. Butir-butir refleksi karakter toleransi tersebut akan mengantarkan kedamaian antar individu di dunia. Temuan dari studi literatur mengungkap aspek dan indikator karakter toleransi yaitu kedamaian, menghargai perbedaan dan individu, serta kesadaran.

Tabel 1. Aspek Karakter Toleransi

\begin{tabular}{|c|l|l|}
\hline No & Aspek Toleransi & \multicolumn{1}{c|}{ Indikator Toleransi } \\
\hline 1. & Kedamaian & $\begin{array}{l}\text { a. Peduli } \\
\text { b. Ketidaktakutan } \\
\text { c. Cinta }\end{array}$ \\
\hline 2. & $\begin{array}{l}\text { Mengahargai } \\
\text { Pebedaan } \\
\text { Individu }\end{array}$ & $\begin{array}{l}\text { a. Saling menghargai satu sama lain } \\
\text { b. Menghargai perbedaan orang lain } \\
\text { c. Menghargai diri sendiri }\end{array}$ \\
\hline 3 & Kesadaran & $\begin{array}{l}\text { a. Menghargai kebaikan orang lain } \\
\text { b. Terbuka } \\
\text { c. Reseptif } \\
\text { d. Kenyamanan dalam kehidupan } \\
\text { e. Kenyamanan dengan orang lain }\end{array}$ \\
\hline
\end{tabular}


Temuan butir pernyataan dari forum group discussion (FGD) dengan pakar/ ahli serta hasil validasi isi menemukan indikator karakter toleransi dan 60 butir pernyataan untuk mengungkap tiga aspek karakter toleransi. Aspek-aspek karakter toleransi yaitu (1) aspek kedamaian meliputi indikator peduli, ketidaktakutan, dan cinta, (2) aspek menghargai perbedaan dan individu meliputi indikator saling menghargai satu sama lain, menghargai perbedaan orang lain, dan menghargai diri sendiri, serta (3) aspek kesadaran meliputi indikator menghargai kebaikan orang lain, terbuka, reseptif, kenyamanan dalam kehidupan, dan kenyamanan dengan orang lain. Butir-butir pernyataan sesuai dengan perkembangan psikologis dan pembelajaran peserta didik dalam mengengkap karakter toleransi siswa SMP.

Uji coba instrumen skala karakter toleransi dilakukan pada 100 responden. Uji validitas dan reliabilitas skala perilaku agresi dibantu dengan aplikasi SPSS 19. Berdasarkan hasil analisis korelasi product moment dapat disimpulkan bahwa dari 50 jumlah total item, 39 item diataranya dinyatakan valid, sehingga 39 item dipertahankan dan sisanya, 11 item dinyatakan gugur. Hasil analisis Alpha Cronbach, koefisien reliabilitasnya adalah 0,777 yang termasuk dalam kategori reliabilitas tinggi. Hasil analisis di atas dapat menjadi dasar untuk menentukan bahwa instrumen skala karakter toleransi layak untuk digunakan untuk mengetahui tingkat karakter toleransi siswa SMP.

Tabel 2. Pernyataan Aspek Kedamaian

\begin{tabular}{|l|}
\hline \multicolumn{2}{|c|}{ Kedamaian } \\
\hline a. Peduli \\
\hline Saya membantu teman saya dari luar daerah jika terkena musibah \\
\hline Menolong teman yang kesulitan masuk ruang kelas saat memakai kursi roda \\
\hline Memahami cara berbicara teman lain yang berbeda tutur bahasa \\
\hline Mendengarkan teman lain yang sedang berbicara di depan kelas \\
\hline b. Ketidaktakutan \\
\hline Bersedia memberikan alamat dan nomor telepon kepada teman dari luar daerah \\
\hline Membantu teman yang tidak disukai oleh teman-teman lain \\
\hline c. Cinta \\
\hline Mengunjungi teman yang sakit walaupun berbeda agama \\
\hline Menyukai perbedaan antara laki-laki dan perempuan \\
\hline Saya tidak menyukai cara beribadah teman lain yang berbeda agama \\
\hline Saya bersedia berdiskusi untuk menemukan solusi jika ada perdebatan \\
\hline Saya menerima teman lain yang tidak sependapat \\
\hline Saya menerima usul dari teman lain yang berbeda agama \\
\hline
\end{tabular}


Tabel 3. Pernyataan Aspek Menghargai Perbedaan dan Individu

\begin{tabular}{|l|}
\hline \multicolumn{1}{|c|}{ Menghargai Perbedaan dan Individu } \\
\hline a. Saling menghargai satu sama lain \\
\hline Saya bersahabat dengan teman dari berbagai daerah \\
\hline Saya tidak keberatan pendirian tempat ibadah agaman lain di lingkungan sekolah \\
\hline Saya memberikan salam kepada teman dari daerah lain \\
\hline Saya tidak menyukai budaya dari daerah lain \\
\hline b. Menghargai perbedaan orang lain \\
\hline Saya berteman tanpa membedakan warna kulit teman lain \\
\hline Saya bersedia satu bangku dengan teman kaya atau miskin \\
\hline $\begin{array}{l}\text { Saya enggan memberikan salam kepada teman yang tidak saya sukai dan berbeda } \\
\text { dengan saya }\end{array}$ \\
\hline Saya tidak menyukai tutur bahasa teman yang berasal dari luar jawa \\
\hline Saya menolong teman yang sedang dalam musibah \\
\hline c. Menghargai diri sendiri \\
\hline Saya menganggap bahwa diri saya yang paling benar dibanding teman lain \\
\hline Saya suka melihat perbedaan yang ada di luar daerah saya \\
\hline Saya senang saat ada diskusi dengan teman lain \\
\hline
\end{tabular}

Tabel 4. Pernyataan Aspek Kesadaran

\begin{tabular}{|l|}
\hline \multicolumn{1}{|c|}{ Kesadaran } \\
\hline a. Menghargai kebaikan orang lain \\
\hline Saya senang jika orang lain memberikan saran kepada saya \\
\hline Bersatu dengan sekolah untuk memajukan sekolah \\
\hline b. Terbuka \\
\hline Bermusyawarah untuk menyelesaikan pertentangan dengan teman di sekolah \\
\hline Saya bermusyawarah dengan semua teman apapun perbedaannya \\
\hline Saya mendukung jika teman yang berbeda agama menjadi pemimpin \\
\hline Menerima saran dari seluruh teman maupun guru \\
\hline c. Reseptif \\
\hline Saya menghargai teman yang mengutarakan pendapatnya pada saat diskusi \\
\hline Saya menghargai perbedaan pendapat dengan teman lain \\
\hline d. Kenyamanan dalam kehidupan \\
\hline Kebersamaan di sekolah menjadi bagian penting kehidupan \\
\hline Berbeda agama dengan teman lain dapat menimbulkan masalah \\
\hline Perbedaan pendapat menimbulkan solusi saat diskusi \\
\hline Perbedaan asal daerah tidak menyebabkan masalah dalam memilih teman \\
\hline e. Kenyamanan dengan orang lain \\
\hline Saya senang jika muncul perbedaan cara berbicara dengan teman \\
\hline Saya bermain dengan teman tanpa membedakan derajat \\
\hline $\begin{array}{l}\text { Saya ingin belajar satu kelompok dengan semua teman tanpa membedakan ganteng } \\
\text { atau cantik }\end{array}$ \\
\hline
\end{tabular}


Layaknya penelitian Wahyudi (2017) menyatakan bahwa sekolah memiliki peran dalam pengembangan pendidikan karakter toleransi beragama yang multikultural, sehingga menumbuhkan sikap menghargai keberagamannya. Penelitian lain yang dilakukan oleh Suciartini (2017) pendidikan adalah tempat tumbuh perbedaan dan menumbuhkan rasa saling menghormati diantara perbedaan. Guru atau pendidik sebagai ujung tombak pendidikan memiliki peran khusus dalam menanamkan toleransi di dunia pendidikan akan menjadi teladan bagi semua. Maka skala karakter toleransi ini dapat digunakan untuk mengetahui tingkat toleransi pada siswa sekolah dan mengembangkan tingkat toleransi dari hasil alat ukur. Supriyanto (2017) menjelaskan bahwa penggunaan assessment yang tepat, relevan, valid, dan reliabel akan sangat mendukung pada proses pelaksanaan dari pendekatan bimbingan maupun konseling.

Hasil penelitian ini dapat disimpulkan bahwa skala karakter toleransi bisa digunakan untuk mengukur tingkat toleransi siswa. Tingkat toleransi siswa yang diketahui dari skala karakter toleransi menjadi dasar untuk menyusun rencana tindakan guna mencegah dan mereduksi intoleransi dikalangan siswa sekolah. Rencana tersebut akan tertuang dalam program Bimbingan dan Konseling yang memandu guru bimbingan dan konseling atau konselor dalam memberikan layanan kepada siswa. Model kelompok panduan berdasarkan nilai karakter lokal java dapat dijadikan alternatif untuk memaksimalkan kualitas layanan bimbingan (Dewi, 2016).

Skala karakter toleransi yang telah dikembangkan ini diharapkan dapat digunakan konselor di sekolah untuk mengidentifikasi tingkat karakter toleransi siswa. Konselor dapat merancang sebuah strategi untuk mengembangkan karakter toleransi dan mencegah fenomenan intoleransi.

\section{KESIMPULAN}

Penelitian ini menemukan butir-butir pernyataan yang valid dan reliabel pada instrumen skala karakter toleransi. Penelitian dilakukan untuk menemukan konsep dan operasionalisasi skala karakter toleransi melalui tiga aspek, yaitu kedamaian, menghargai perbedaan dan individu, serta kesadaran. Aspekaspek karakter toleransi yaitu (1) aspek kedamaian meliputi indikator peduli, ketidaktakutan, dan cinta, (2) aspek menghargai perbedaan dan individu meliputi indikator saling menghargai satu sama lain, menghargai perbedaan orang lain, dan menghargai diri sendiri, serta (3) aspek kesadaran meliputi indikator menghargai kebaikan orang lain, terbuka, reseptif, kenyamanan dalam kehidupan, dan kenyamanan dengan orang lain.

Skala karakter toleransi memiliki 39 butir pernyataan yang valid. Koefisien reliabilitas skala karakter toleransi adalah 0,777 yang termasuk dalam kategori reliabilitas tinggi. Hasil penelitian berupa skala karakter toleransi dapat digunakan oleh konselor untuk mengidentifikasi 
tingkat karakter toleransi siswa di sekolah.

\section{DAFTAR PUSTAKA}

Andersen, R., \& Fetner, T. (2008). Economic inequality and intolerance: Attitudes toward homosexuality in 35 democracies. American Journal of Political Science, 52(4), 942-958.

Dewi, N. K. (2016). Pengembangan Model Bimbingan Kelompok Berbasis Nilai Karakter Lokal Jawa untuk Meningkatkan Kesadaran Diri (Self Awareness) Siswa. Counsellia: Jurnal Bimbingan dan Konseling, 3(1).

Elias, M. J., Parker, S. J., Kash, V. M., Weissberg, R. P., \& O'Brien, M. U. (2008). Social and emotional learning, moral education, and character education: A comparative analysis and a view toward convergence. Handbook of moral and character education, 248-266.

Galtung, J. (1967). Theories of Peace: A Synthetic Approach to Peace Thinking. Oslo: International Peace Research Institute.

Galtung, J., \& Fischer, D. (2013). Positive and negative peace. In Johan Galtung. Springer Berlin Heidelberg. 173-178.

Giugni, M., \& Morariu, M. (2010). Intolerance begets intolerance: Explaining negative attitudes towards foreigners and Muslims in Switzerland, 1996-
2007. In: Simon Hug and Hanspeter Kriesi. Value change in Switzerland. Lexington Books.

Khan, T., Österman, K., \& Björkqvist, K. (2017). Severity and Reasons Behind Religious Intolerance in Pakistan: Perceptions of Sunnis, Shias, Ahmadis, and Christians. EJSER European Journal of Social Sciences Education and Research Articles, 10(2), 193-202

Marshall, J. C., Caldwell, S. D., \& Foster, J. (2011). Moral education the character. Journal of Moral Education, 40(1), 51-72.

Nurdin, E. S. (2015). The Policies on Civic Education in Developing National Character in Indonesia. International Education Studies, 8(8), 199209.

Parker, D. C., Nelson, J. S., \& Burns, M. K. (2010). Comparison of correlates of classroom behavior problems in schools with and without a school-wide character education program. Psychology in the Schools, 47(8), 817-827.

Richardson, R. C., Tolson, H., Huang, T. Y., \& Lee, Y. H. (2009). Character education: Lessons for teaching social and emotional competence. Children \& Schools, 31(2), 71-78.

Sanderse, W. (2013). The meaning of role modelling in moral and character education. Journal of Moral Education, 42(1), 28-42. 
70 Jurnal Ilmiah Counsellia, Volume 7 No. 2, Nopember 2017 : 61 - 70

Setiawan, D. (2015). Kasus Intoleransi, DI Yogyakarta Diminta Waspada (Ed). regional.kompas.com.

Suciartini, N. N. A. (2017). Urgensi Pendidikan Toleransi dalam Wajah Pembelajaran sebagai Upaya Meningkatkan Kualitas Pendidikan. Jurnal Penjaminan Mutu, 3(1), 12-22.

Sultoni, A., \& Hilmi, H. S. (2015). Pembelajaran Sastra Berbasis Kearifan Lokal Sebagai Upaya Optimalisasi Pendidikan Karakter Kebangsaan Menuju Masyarakat Ekonomi ASEAN (MEA). Proceedings. Seminar Nasional Pendidikan Bahasa Indonesia.

Supriyanto, A. (2017). Rehabilitation Counseling: Concept Assessment Guidance and Counseling For Drugs Abuse. In Prosiding Seminar Nasional Bimbingan Konseling (Vol. 1, No. 1, pp. 19-30).
Tillman, Diane. 2004. Pendidikan Nilai Untuk Kaum Muda Dewasa (Terjemahan Risa Pratono). Jakarta: Grasindo

Trisiana, A. (2015). Action for Citizenship Education of Character Education Using Project Citizen Model at Senior High School In Indonesia. International Journal of Education and Psychology in the Community, 5(1/2), 42-53

Wahyudi, A. (2017). Character Education: Literatur Study Religious Tolerance Character. In Prosiding Seminar Nasional Bimbingan Konseling (Vol. 1, No. 1, pp. 49-56).

Wang, L. (2017). What Does It Mean to Be Canadian? Building National Identity for Secondary Students Through History. University of Toronto. 